\title{
Citra Perusahaan Traveloka Terhadap Kepuasan dan Loyalitas Pelanggan
}

\section{Oleh:}

Nada Nabigha Adria ${ }^{1}$, Niken Febrina Ernungtyas ${ }^{2}$

${ }^{12}$ Sekolah Tinggi Ilmu Komunikasi Inter Studi

11nadanabigha24@yahoo.com, 2niken@stikom.interstudi.edu

\begin{tabular}{l}
\hline Keywords: \\
\hline Travel; tourism; \\
loyalty; customer \\
satisfaction; \\
company image. \\
\hline
\end{tabular}

Kata kunci:

Pariwisata,

Loyalitas;

kepuasan

Pelanggan, Citra

Perusahaan

\begin{abstract}
This article discusses the impact of company image, customer satisfaction on customer loyalty in travel agents. A corporate image model, customer satisfaction. customer loyalty is developed and tested. Direct and indirect relationship between three variables. The key implication for travel agents is to build strong emotional ties with customers and enhance the company's image through trust and service delivery. Therefore, understanding is very important to examine, this research aims to understand how the company's image potential in increasing customer satisfaction and loyalty. This study uses a quantitative method by distributing questionnaires to 76 respondents. Data processing is done by ssps. The results of the study show that company image and customer satisfaction can increase customer loyalty.
\end{abstract}

\begin{tabular}{l} 
Abstrak \\
\hline Artikel ini membahas dampak citra perusahaan, kepuasan \\
pelanggan terhadap loyalitas pelanggan dalam agen biro \\
pejalanan. Sebuah model citra perusahaan, kepuasan pelanggan. \\
hasian terhadap loyaltas pelanggan dikembangkan dan diuji. \\
Hubungan langsung dan tidak langsung antara tiga variable. \\
Kunci implikasi bagi agen perjalanan adalah membangun ikatan \\
emosional yang kuat dengan pelanggan dan meningkatkan citra \\
perusahaan melalui kepercayaan dan pemberian layanan. Oleh \\
karena itu pemahaman sangat penting untuk di teliti, penelitian \\
ini berujuan untuk memahami bagaimana potensi citra \\
perushaan dalam meningkatkan kepuasan dan loyalitas \\
pelanggan. Penelitian ini menggunakan metode kuantitaif \\
melalui pendistribudian kuesioner terhadap 76 responden. \\
Pengolahan data dilakukan dengan ssps. Hasil dari penelitian \\
menunjukan bahwa citra perusahaan dan kepuasan pelanggan \\
dapat meningkatkan loyalitas pelanggan.
\end{tabular}




\section{Pendahuluan}

Penelitian ini membahas pengaruh citra perusahaan terhadap kepuasan dan loyalitas pelanggan pada aplikasi agen perjalanan online Traveloka. Citra perusahaan merupakan salah satu aset penting bagi organisasi yang selayaknya harus terus menerus dibangun dan dipelihara. Namun berbagai peristiwa dapat berimplikasi pada citra, baik dalam bentuk positif dan negatif. Seharusnya hal ini menjadi pelajaran berharga bagi perusahaan, termasuk agen perjalanan online Traveloka (Zulfiah, 2020). Traveloka merupakan salah satu dari lima besar agen perjalanan online di Indonesia. Pada tahun 2019, Traveloka memiliki masalah dengan krisis citra yang menyebabkan turunnya jumlah pengguna aplikasi. Dari data Jakarta Urban Hosting 2017 , menunjukkan bahwa rank usage Traveloka menurun dari 24675 menjadi 25536 rank usege, hal ini dapat diertikan bahwa terdapat potensi penurunan pengguna atau pengunduh aplikasi Traveloka sekitar 3,5\% (Jakarta Urban Hosting, 2017).

Fenomena ini menarik untuk dikaji bagaimana krisis pada citra perusahaan Traveloka berpengaruh terhadap loyalitas dan kepuasan pelanggannya. Tentunya, dampak sosial media terhadap reputasi bisnis secara negative akan menjadi pada kerugian yang cukup besar maka untuk mencapai tujuan tersebut perusahaan harus dapat menunjukan atau membuat citra positif kembali agar pelanggan tetap puas dan loyal (Wirawan, 2020). Hal ini menjadi persoalan serius bagi perusahaan untuk mengatasi krisis dengan segala bentuk usaha yang dibangun mendapatkan feedback baik dan postif dari pelanggan mengenai kasus \#UninstallTraveloka sekaligus mendorong masyarakat lain untuk mencoba menggunakan aplikasi Traveloka (Widiantara, 2020). Salah satu cara untuk membangun citra yang positif membangun nilai-nilai kepercayaan komunikasi, pelayanan dan periklanan di media sosial karena berdampak cukup besar (Aminah, 2020). Sampai saat ini, media sosial masih dinilai yang paling aktif dalam menjangkau khalayak, guna membangun dan mempertahankan loyalitas dan kepuasan pelanggan suatu produk atau perusahaan (Zulfikar, 2019). Untuk mendapatkan loyalitas pelanggan sebuah perusahaan juga harus memperhatikan citra (Ikhsana, 2019). Selain itu, hubungan yang berkelanjutan antara perusahaan dan pelanggan sangat penting untuk mengkomunikasikan pesan diantara kedua belah pihak (Herika, 2018).

Citra adalah persepsi masyarakat terhadap organisasi didasari pada apa yang mereka ketahui atau mereka kira tentang organisasi yang bersangkutan. Citra yang baik merupakan salah satu alat yang penting bagi setiap perusahaan, bukan hanya untuk 
menarik konsumen dalam memilih produk atau jasa, melainkan juga dapat memperbaiki sikap kepuasan pelanggan terhadap organisasi/perusahaan (Papeo, 2018).

Kepuasan pelanggan adalah sebagai keseluruhan sikap yang ditunjukan konsumen atas jasa setelah mereka menggunakanya ini merupakan pengalaman menggunakan jasa pasca pembelian, pelanggan akan mengevaluasi kinerja produk sesuai dengan yang diharapkan. Tanggapan emosional ini bertindak sebagai masukan atau input dalam persepsi kepuasan/ ketidak puasan (Kurriwati, 2012). Kepuasan pelanggan sebagai suatu perasaan konsumen sebagai respon terhadap jasa yang telah dikonsumsi, dapat diartikan sebagai suatu perbandingan antara layanan atau hasil yang diterima konsumen dengan harapan hasil yang diterima itu paling tidak harus sama dengan harapan konsumen (Normasari, 2013).

Loyalitas pelanggan lebih mengacu kepada wujud perilaku dari unit-unit pengambilan keputusan untuk melakukan pembelian secara terus menerus terhadap barang atau jasa suatu perusahaan yang dipilih. Maka loyalitas terbentuk karena adanya pengalaman dalam menggunakan suatu barang atau jasa (Normasari et al., 2013). Dampak sosial media terhadap reputasi bisnis secara negative akan menghasilkan kerugian bisnis yang cukup besar. Hal ini hanya dilihat dari sisi biaya per instalasi, belum membahas tentang potensi pendapatan atas transaksi pembelian tiket. Dari kejadian tersebut, dapat dipahami bahwa dampak sosial media terhadap reputasi bisnis cukup signifikan. Maka dari itu harus diakui bahwa respon yang cepat terhadap isu negative (dan juga positive) sangat diperlukan. Media sosial merupakan tempat untuk berinteraksi.

Mengenai kasus \#uninstalltraveloka, pihak Traveloka merespon melalui saluran digital yang memiliki "attack rate" yang kurang cepat sehingga banyak yang menyimpulkan bahwa pihak Traveloka tidak merespon tentang kasus ini. Press release dari Traveloka merupakan sebuah respon yang cukup baik dan tentunya diharapkan dapat meredam aksi tersebut. Akan tetapi tagar \#UninstallTraveloka tetap terlihat di hari kedua. Dapat disimpulkan untuk mendapatkan merespon isu negative, perusahaan perlu terjun langsung ke saluran digital yang memiliki pengaruh yang signifikan. Pada akhinya, terdapat penurunan penggunaan aplikasi ticketing yang berpotensi memberikan kerugian pada perusahaan dengan jumlah milyaran rupiah. Selanjutnya, citra brand dapat terancam menurun. Jika ini terjadi, maka biaya untuk membangun brand tersebut dapat menjadi sebuah intangible cost yang perlu di hitung. Untuk dapat melakukan respon cepat, perusahaan harus memiliki pemantauan sosial media (social media monitoring). Dengan 
cara ini, isu negative dan positif tidak hanya dapat dikumpulkan, akan tetapi trend dan influencer juga dapat di kumpulkan untuk analisa lebih lanjut. Selanjutnya, dari data isu tersebut, dapat lakukan strategi PR (Public Relation) dengan memberikan tanggapan, pemahaman, penelusuran masalah, dan sebagainya. Hal ini dapat dilihat pada perusahaan jasa telekomunikasi dan e-commerce, mereka selalu aktif menangani keluhan di sosial media dan menawarkan solusi melalui DM (direct message), sehingga dapat meredam dampak sosial media yang buruk terhadap reputasi bisnis.

Mempertahankan pelanggan berarti mengharapkan pelanggan melakukan pembelian ulang kembali terhadap jasa pada saat kebutuhan yang sama muncul sewaktuwaktu (Sembiring, 2014). Kepuasan pelanggan atas kinerja jasa perusahaan tergantung banyak faktor terutama jenis loyalitas yang dimiliki pelanggan dengan sebuah citra dan strategi kepuasan pelanggan harus didasari dengan suatu pengetahuan yang detail dan akurat. Respon citra perusahaan terhadap loyalitas pelanggan merupakan ukuran kesetiaan seorang pelanggan pada sebuah citra (Iriandini, 2015). Kepuasan pelanggan sangat berpengaruh terhadap timbulnya loyalitas pelanggan Salah satu faktor yang mempengaruhi terjadinya loyalitas adalah tingkat kepuasan pelanggan (Gaol, 2016). Kepuasan pelanggan ini terjadi akibat dari produk atau jasa yang digunakan sesuai dengan keinginan atau harapan pelanggan (Gaol et al., 2016).

Kepuasan pelanggan berpengaruh positif terhadap loyalitas pelanggan, citra perusahaan berpengaruh positif terhadap loyalitas pelanggan. Penelitian tersebut juga didukung oleh hasil penelitian Andreassen, Lindestad (1998) yang menyatakan bahwa citra perusahaan dan kepuasan pelanggan berpengaruh secara signifikan terhadap loyalitas pelanggan (Kurriwati, 2012).

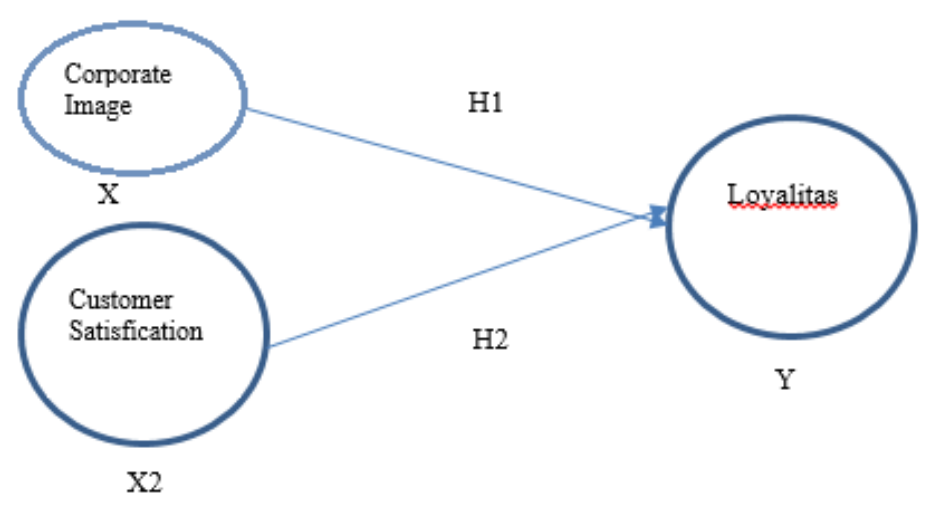

Gambar 1. Variabel Citra Perushaan terhadap Loyalitas Pelanggan dan Kepuasaan Pelanggan terhadap Loyalitas Pelanggan 
Hipotesis penelitian untuk menjelaskan mengenai pengaruh dari variabel Citra Perushaan terhadap Loyalitas Pelanggan dan Kepuasaan Pelanggan terhadap Loyalitas Pelanggan. Berdasarkan penjelasan dan tujuan penelitian, studi ini mengajukan dua hipotesis yaitu:

H1: Citra Perusahaan berpengaruh signifikan terhadap Loyalitas Pelanggan

H2 : Kepuasan Pelanggan berpengaruh signifikan terhadap Loyalitas Pelanggan

\section{Metode}

Penelitian ini menggunakan paradigma positivistik untuk menjelaskan hubungan antara citra perusahaan terhadap kepuasan dan loyalitas pelanggan. Paradigma positivistik digunakan karena penelitian ini menunjukan penelitian kuantitatif, yang mengkaji fenomena secara empiris dan terukur. Dalam melibatkan populasi pengguna aplikasi Traveloka, karena generasi SMA pasar potensial bagi Traveloka dimana akan datang. Jumlah sampel yang digunakan dalam penelitian ini sebanyak 57 konsumen karena sesuai dengan kriteria yaitu (menggunakan traveloka, melakukan transaksi minimal 1 kali dalam 3 bulan terakhir). Penelitian ini diukur dengan menggunakan skala likert 5 poin. Skor Jawaban responden terdiri dari lima jawaban yaitu sangat setuju, setuju, ragu-ragu, tidak setuju, dan sangat tidak setuju. Variabel penelitian ini terdiri tiga yaitu citra perusahaan, kepuasan dan loyalitas.

Tabel 1.

Hasil Uji Regresi Linier

\begin{tabular}{|l|l|}
\hline Variabel & Indikator \\
\hline Citra perusahaan & $\begin{array}{l}\text { 1. Menurut Saya, citra biro perjalanan Traveloka ini baik } \\
\text { 2. Perasaan positif Saya terhadap biro perjalanan ini adalah } \\
\text { alasan utama mengapa Saya terus membeli layanan } \\
\text { perjalanan dari Traveloka }\end{array}$ \\
& $\begin{array}{l}\text { 3. Persepsi Anda tentang citra perusahaan dari Traveloka } \\
\text { ini sangat menguntungkan bagi penggunanya }\end{array}$ \\
& $\begin{array}{l}\text { 4. Dibandingkan dengan biro perjalanan lain, Traveloka } \\
\text { menyediakan fitur yang lengkap untuk Anda }\end{array}$ \\
\hline Kepuasan pelanggan & $\begin{array}{l}\text { 1. Saya akan terus membeli layanan perjalanan dari } \\
\text { Traveloka dalam beberapa tahun ke depan }\end{array}$ \\
& $\begin{array}{l}\text { 2. Menurut Saya, fitur yang disediakan Traveloka cukup } \\
\text { lengkap dan mudah digunakan para penggunanya }\end{array}$ \\
\hline 2. Saya puas terhadap biro perjalanan Traveloka ini
\end{tabular}




\begin{tabular}{|l|l|}
\hline 2. Saya akan merekomendasikan Traveloka kepada \\
seseorang yang meminta saran saya mengenai biro \\
perjalanan \\
$\begin{array}{l}\text { 3. Saya menganggap Traveloka menjadi pilihan pertama } \\
\text { saya dalam membeli layanan perjalanan }\end{array}$ \\
\hline
\end{tabular}

Kepuasan pelanggan terdiri dari 3 indikator dan loyalitas pelanggan terdiri dari 3 indikator. Ketiga variabel ini diadopsi dari journal marketing of management (may, 2012). Kuesioner dibuat secara online menggunakan google form disebarkan melalui media sosial berdasarkan kriteria responden. Responden mengisi sendiri kuesioner tersebut atau disebut dengan self-reported. Kuesioner terdiri dari tiga bagian yaitu (1) lembar persetujuan menjadi responden, (2) data demografi, dan (3) variabel. Data demografi terdiri dari (1)jenis kelamin (2)usia (3) kelas di sekolah. Data yang terkumpul selanjutnya dianalisis dengan analisis univariat dan bivariat menggunakan aplikasi SPSS. Variabel selanjutnya diukur validitas dan reliabilitas untuk melihat konsistensi dan keabsahan alat ukur. Validitas diukur dengan nilai KMO dan reliabilitas diukur dengan nilai Cronbach Alpha.

\section{Hasil dan Pembahasan}

Penelitian ini menganalisis data dari responden $(\mathrm{N}=76)$ dengan analisis unvariat dan bivariat. Berdasarkan analisis univariat mayoritas responden bersekolah di SMA 17 Agustus 1945 di kota jakarta selatan (100\%) dan responden terdiri dari mayoritas pria (54\%) dengan mayoritas usia 18-19 tahun (14\%) di kelas 12 (85\%).

Tabel 2.

Hasil Uji Unvariat

\begin{tabular}{|l|l|l|}
\hline & Kategori & F (\%) \\
\hline SMA 17 Agustus 1945 & Ya & $100(100 \%)$ \\
\hline & Tidak & $0 \%(0 \%)$ \\
\hline Jenis Kelamin & Pria & $54 \%(54 \%)$ \\
\hline & Wanita & $46 \%(46 \%)$ \\
\hline Usia & $14-15$ Tahun & $0 \%(0 \%)$ \\
\hline & $16-17$ Tahun & $26 \%(26 \%)$ \\
\hline & $18-19$ Tahun & $73 \%(73 \%)$ \\
\hline Kelas & Kelas10 & $0 \%(0 \%)$ \\
\hline & Kelas 11 & $14 \%(14 \%)$ \\
\hline & Kelas 12 & $85 \%(85 \%)$ \\
\hline
\end{tabular}


Selanjutnya uji validitas dan realibilitas menunjukan seluruh variabel dan realibel. Ketiga variabel menunjukan nilai Keiser-Meyer Olkin (KMO) lebih dari 0,5. Sedangkan nlai Croanbach Alpha seluruh variabel menunjukan angka diata 0.7. hasil uji validitas dan realibiliras ada di tabel 1 berikut.

Tabel 3.

Hasil Uji Validitas

\begin{tabular}{|l|l|l|l|}
\hline Variabel & KMO & $\alpha$ & Keterangan \\
\hline Citra Perusahaan & 0.849 & 0.945 & Valid \\
\hline $\begin{array}{l}\text { Kepuasan } \\
\text { Pelanggan }\end{array}$ & 0.753 & 0.911 & Valid \\
\hline $\begin{array}{l}\text { Loyalitas } \\
\text { Pelangaan }\end{array}$ & 0.747 & 0.935 & Valid \\
\hline
\end{tabular}

Uji hipotesis penelitian ini selanjutnya dilakukan analisis bivariat dengan analisis regresi linier sederhana. Seluruh hipotesis terbukti dan signifikan secara statistik dengan nilai signifikasi dibawah 0.05 . Hipotesis pertama menunjukan perhatian citra perusahaan secara positif berpengaruh terhadap loyalitas pelanggan $(\mathrm{Sig}=0.000)$ dengan besar pengaruh sangat kuat $(\mathrm{R}=0.900)$ dan menjelaskan 0.809 varians. Kemudian hipotesis kedua menunjukan adanya pengaruh variabel pengaruh pada kepuasan pelanggan terhadap loyalitas pelanggan $(\mathrm{Sig}=0.000)$ dan pengaruh ini terbukti sangat kuat $(\mathrm{R}=0.927)$.

Table 4.

Hasil uji Hipotesis

\begin{tabular}{|l|l|l|l|}
\hline Hipotesis & R & R Square & Sig \\
\hline $\begin{array}{l}\text { H1 Citra } \\
\text { Perusahaan } \\
\text { Traveloka - } \\
\text { kepuasaan } \\
\text { pelanggan }\end{array}$ & 0.900 & 0.809 & 0.000 \\
\hline $\begin{array}{l}\text { H2 Kepuasan } \\
\begin{array}{l}\text { Pelanggan - } \\
\text { Loyalitas pelanggan } \\
\text { traveloka }\end{array}\end{array}$ & 0.927 & 0.860 & \\
\hline
\end{tabular}

Setelah dilakukan analisis dengan penjelasan di atas, pada bagian ini membahas dan mendiskusikan mengenai perbandingan hasil dalam penelitian ini dengan penelitian sebelumnya yang dijadikan sebagai acuan serta kajian literatur pada penelitian ini. Dari yang dilakukan dalam penelitian ini dan penelitian sebelumnya, terlihat bahwa dari 
masing-masing variabel Citra perushaan terhadap Loyalitas Pelanggan memiliki hasil yang memenuhi syarat. Berikut digambarkan perbedaan hasil dari masing-masing variabel.

Terlihat bahwa terdapat perbedaan nilai antara penelitian ini dengan penelitian terdahulu (Normasari, Kumadji, \& Kusumawati, 2013), dimana hasil dari penelitian terdahulu menunjukkan pengaruh langsung variabel citra perusahaan terhadap variabel loyalitas pelanggan dengan nilai koefisien $(\beta)$ sebesar 0,386 (Rendah) dan thitung sebesar 4,785. Pengaruh ini signifikan dengan nilai p-value sebesar 0,000 (p<) H0 ditolak, maka hipotesis yang menyatakan bahwa pengaruh siginifikan variabel citra perusahaan terhadap variabel loyalitas pelanggan diterima dengan kontribusi sebesar 43,30\%.

Pada variabel kepuasan pelanggan terhadap variabel loyalitas pelanggan menunjukkan pengaruh langsung dengan nilai koefisien $(\beta)$ sebesar 0,373 (Rendah) dan thitung sebesar 4,446. Pengaruh ini signifikan dengan nilai p-value sebesar 0,000 ( $<<$ ) H0 ditolak, maka hipotesis yang menyatakan bahwa pengaruh signifikan variabel kepuasan pelanggan terhadap variabel loyalitas pelanggan diterima dengan kontribusi sebesar 43,30\%. Sementara itu pada penelitian ini menunjukan pengaruh Citra Perusahaan terhadap variabel Loyalitas Pelanggan dengan pengaruh sangat kuat $(\mathrm{R}=0.900)$ dan menjelaskan 0.809 varians. Pada variabel Kepuasan pelanggan terhadap variabel loyalitas pelanggan terdapat pengaruh yang sangat kuat $(\mathrm{R}=0.927)$ dan menjelaskan 0.860 varians.

Adanya perbedaan ini disebabkan oleh perbedaan jumlah indikator atau butirbutir dalam kuesioner, kemudian perbedaan karakteristik responden dari segi demografis serta teknik sampling yang digunakan. Namun pada prinsipnya, hasil penelitian ini sejalan dengan penelitian terdahulu yang dijadikan sebagai kajian literatur,

\section{Kesimpulan}

Berdasarkan hasil analisis data yang telah dilakukan penelitian mengenai citra perusahaan traveloka terhadap kepuasan dan loyalitas pelanggan di kalangan dapat ditarik kesimpulan. Citra perusahaan Traveloka tidak berpengaruh di kalangan masyarakat khusus nya SMA 17Agustus 1945 hal ini membuktikan tingkat signifikan artinya citra perusahan Traveloka tidak berpengaruh terhadap kasus \#UnInstallTraveloka. Hipotesis pertama menunjukan perhatian citra perusahaan secara positif berpengaruh terhadap loyalitas pelanggan dengan besar pengaruh moderat dan menjelaskan varians. Kemudian 
hipotesis kedua menunjukan adanya pengaruh variable pengaruh pada kepuasan pelanggan terhadap loyalitas pelanggan dan pengaruh ini terbukti kuat. Artinya hipotesis pertama dan kedua terbukti positif dan berpengaruh. Kepada penelitian selanjutnya di bidang ilmu komunikasi, disarankan agar menggali lebih dalam lagi terkait citra perusahaan dan kepuasan pelanggan terhadap loyalitas pelanggan. Karena banyak perusahaan yang berhasil dari sisi promosi namun hanya sedikit yang mempunyai keistimewaan di benak konsumen.

\section{Daftar Pustaka}

Aminah, R. S. (2020). Komunikasi Pemasaran Terpadu Pariwisata Berbasis ke Arifan Lokal di Kota Bogor. Ganaya : Jurnal Ilmu Sosial Dan Humaniora, 2(2-3), 122129. https://doi.org/10.1017/CBO9781107415324.004

Gaol, A. L., Hidayat, K., \& Sunarti. (2016). Pengaruh Kualitas Produk terhadap Tingkat Kepuasan Konsumen dan Loyalitas Konsumen (Survei pada Mahasiswa S1 Fakultas Ilmu Administrasi Tahun Akademik 2012/2013 Universitas Brawijaya yang Menggunakan Smartphone Samsung). Jurnal Administrasi Bisnis, 38(1), $125-132$.

Herika, D., \& Ruliana, P. (2018). Public Relations dalam Membina Hubungan dengan Media. Inter Komunika: Jurnal Komunikasi, 3(01), 45-58.

Ikhsana, P. D., Prisanto, G. F., \& Anggraini, R. (2019). Penerapan Strategi E-Marketing Communication dan Ekuitas Merek Siaranku.com Terhadap Loyaliyas Viewers. Inter Komunika: Jurnal Komunikasi, 4(1), 58-74.

Iriandini, A. P., Yulianto, E., \& Mawardi, M. K. (2015). Pengaruh Costumer Relationship Management (CRM) terhadap Kepuasaan Pelanggan dn Loyalitas Pelanggan (Survey pada Pelanggan PT. Gemilang Libra Logistics, Kota Surabaya). Jurnal Administrasi Bisnis, 23(2), 1-8.

Jakarta Urban Hosting. (2017). Dampak Sosial Media Pada Reputasi Bisnis Dan Contoh Kasus. Retrieved January 27, 2020, from Jakartaurbanhosting.com website: https://jakartaurbanhosting.com/dampak-sosial-media-pada-reputasi-bisnis/

Kurriwati, N. (2012). Pengaruh Kualitas Produk Terhadap Kupuasan dan Dampaknya Terhadap Loyalitas Konsumen. Jurnal Manajemen Pemasaran Petra, 1(1), 48-55. Retrieved from http://journal.trunojoyo.ac.id/ecoentrepreneur/article/view/994/893 
Normasari, S., Kumadji, S., \& Kusumawati, A. (2013). Pengaruh Kualitas Pelayanan terhadap Kepuasan Pelanggan, Citra Perusahaan dan Loyaltas Pelanggan (Survei pada Tamu Pelanggan yang Menginap di Hotel Pelangi Malang). Jurnal Administrasi Bisnis, 6(2), 1-9.

Papeo, A., Kalangi, J. A. ., \& Punuindoong, A. (2018). Pengaruh Komunikasi Pemasaran Terhadap Citra Perusahaan PT. Telkom Indonesia Manado. Jurnal Administrasi Bisnis, 6(3), 69-78.

Sembiring, I. J., Suharyono, \& Kusumawati, A. (2014). Pengaruh Kualitas Produk dan Kualitas Pelayanan Terhadap Kepuasan Pelanggan dalam Membentuk Loyalitas Pelanggan (Studi pada Pelangan McDonald's MT. Haryono Malang). Jurnal Administrasi Bisnis, 15(1), 1-10.

Siringo Ringo, R. L., \& Wirawan, I. G. N. P. D. (2020). Strategi Komunikasi Stakeholder dalam Pengembangan Wisata Baru Berbasis Alam dan Budaya pada Obyek Wisata Kuta Mandalika Lombok. Ganaya: Jurnal Ilmu Sosial Dan Humaniora, 2(2-3), $46-53$.

Widiantara, I. K. A. (2020). Strategi Public Relations Pemprov Bali Menuju Bali Bebas Sampah Plastik. Ganaya: Jurnal Ilmu Sosial Dan Humaniora, 2(2-3), 84-91. https://doi.org/10.1017/CBO9781107415324.004

Zulfiah, L., Sumandi, D., \& Herman, L. O. (2020). Peran Public Relations Dalam Membangun Citra Perushaan Melalui Program Corporate Social Responsibilty PT. Antam Tbk. Kolaka Sulawesi Tenggara. Ganaya: Jurnal Ilmu Sosial Dan Humaniora, 2(2-3), 114-152. https://doi.org/10.1017/CBO9781107415324.004

Zulfikar, A. S., \& Yuliaty, K. (2019). Pengaruh Iklan dan Promosi Penjualan di Televisi Terhadap Brand Awareness Bukalapak pada Pengunjung Kota Kasablanka. Inter Komunika: Jurnal Komunikasi, 4(1), 17-26. 